\title{
ビゼンクラゲの口腕付近に見出される カニについて
}

\author{
插四 2 \\ 鈴 木 克 美 \\ (金沢水族館)
}

On a young crab found near the oral arms of the jellyfish, Rhopilema esculenta KISHINOUYE

With 2 Text-Figures

Katsumi SuzukI

(Kanazawa Aquarium)

材料

1962年10月 5 日相模湾江ノ島沖で採集され，汇ノ島水族館の観覧水槽に飼育展示された 众の直径約 $20 \mathrm{~cm}$ のビゼンクラゲ Rhopilema esculenta KISHINOUYE 2 個体のらち 1 個 体の口腕附近に，2 個体の小型のカニが生棲しているのを発見し，観察する機会を得た。 このビゼンクラゲは，カニと共に同年10月22日まで飼育されたが，同日に至り傘の破損が 著しくなったので, 上記のらち1個体のカニをとりあげ, 70\%アルコール液浸標本として 種の同定を行った。

\section{同 定 結 果・記 載}

このカニは，下述の特徴からシマイシガニ Charybdis cruciata (HERBST) と同定さ れた。成体の記載(詳) に比較すると, 甲殼前縁の形態と前側縁第 1 歯が明膫な 2 葉に分た れていないこととが異なるが，その他の特徵が一致し，腹肢がまだほとんど痕跡程度であ ることから見て，この種の初期幼蟹期と思われる。以下に各部の特徵を記載する。

甲長 $97 \mathrm{~mm}$ ，甲幅 $129 \mathrm{~mm}$ 。甲殼背面には毛及び顆粒なく平滑で各域をへだてる溝は明 瞭である。側棘より甲背中央への稜線は顕著でこれより後方には稜線は認められない。甲 背面には前後に走る 4 条の不規則な形の幅広い淡紫褐色条斑があり, 中央の 2 条は輪廓明 瞭で長く, 外側の 2 条は短かく輪廓不明瞭である。これらの条斑は70\%アルコール液浸に よって消失する。

(註) Herbst の原記載及び Ch. cruciata とした Rathbun（1906）の記載は参照し得なかった。 


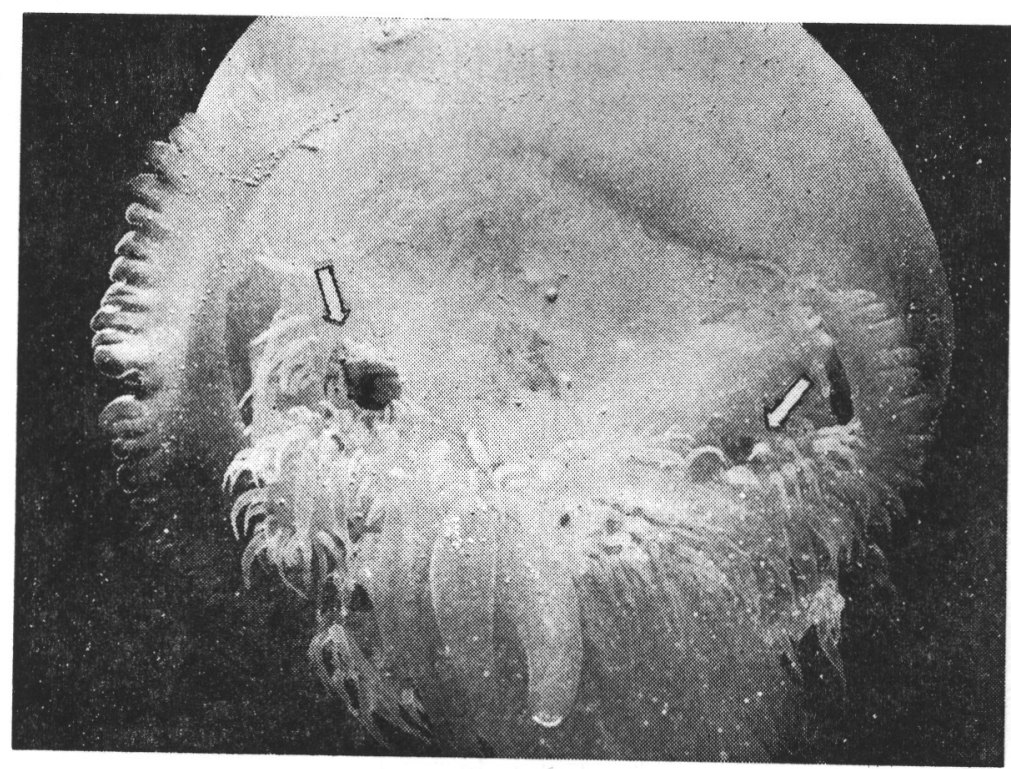

Fig. 1 ビゼンクラゲに伴らカニ 2 個体（矢印）を示す。 $\left(\right.$ 約 $\times 1 \frac{1}{2}$ )

Showing two young crabs accompanying the jellyfish, $R$. escutenta. (arrows)

甲殸前縁は 6 葉に分たれ, 眼前部よりやや突出する。各葉は何れも先端とがらず，中央 2 葉は最も幅せまく, これにつづく 2 葉はこれより幅広い。最子外側の 2 葉も幅広いが, 中央やや凹几で低く，眼前葉となっている。

甲豰前側縁は 6 歯。第 1 歯を除いて何孔も先端鋭くとがり, このらち第 6 歯を除いて基 部広く同大。第 1 歯は最も幅広く, 先端はとがらず, その中央部はわずかに凹む。第 6 霜 は基部せまく，先端は長大で側棘となって側方に突出している。

鉗脚には毛または顆粒なく平滑。長節には前縁に 3 棘並ぶ。腕節は内角に 1 大棘, 外側 に 3 小棘。掌節は基部に 1 棘, その上方に 1 棘, これに並えで内側に 2 棘あり, 後縁には 棘及び顆粒を認めない。

\section{観察}

飼育期間中, カニは 2 個体ともクラゲ口腕附近の半ば身をかくせるようなほぼ一定の位 置にいて，若干移動するだけで，すぐもとの場所杘り， 口腕部を活潑に移動したり，ク ラゲを離れて自由に游泳したりするようすは見られなかった。クラゲの口腕の縫合褶や系 状附属器を銝脚でつまみとり, 口へはこんでいるのがふつうに観察され, 上述の小移動も 摂食のためのように思われた。

飼育期間中若干の成長が認められた。

同定を果せなかった他の 1 個体は，10月22日までに見失ったものである。 


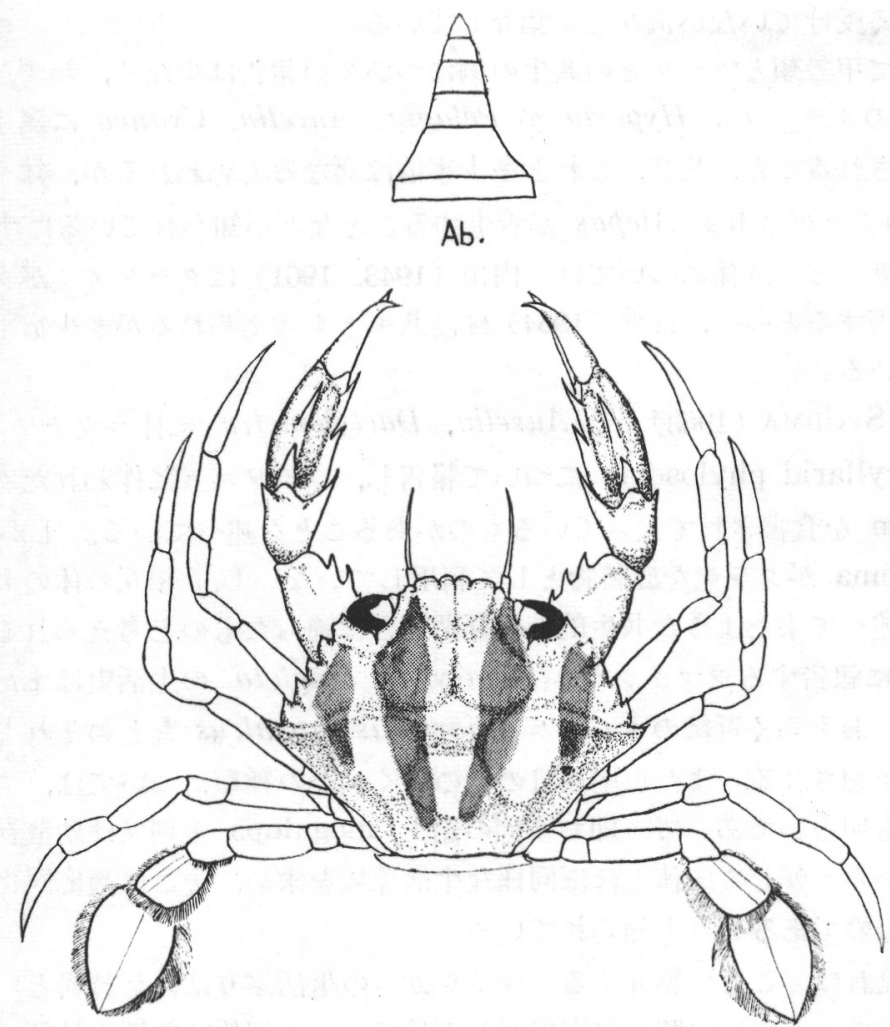

Fig. 2 Charybdis cruciata (HERBST) $\times 5$ juvenile male C. L. $97 \mathrm{~mm}$ C.W. $129 \mathrm{~mm}$

論

議

クラゲとイボダイ科などの幼魚との共生の事実はすでによく知られているが，これにつ いての見解はさまざまである。たと党ば KATO (1933) はエボシダイ Nomeus とカッオ ノエボシ Physalia との共生について, これが従来信じられて来たよらな友好的な関係に あるものではないことを指摘し，庄島 $(1961,1962)$ は, ミズクラゲ Aurelia aurelia, エチゼンクラゲ Stomatophus uomurai, アカクラゲ Dactylometra pacifica 等から イボダイ科 Psenopsis sp., マアジ科のマルアジ Decapterus maruadzi, マアジ Trachurus japonicus の幼魚を得て，イボダイ科幼魚の胃中からはクラゲの生殖腺が発 見されるが，マアジ科幼魚の胃中からは，クラゲと直接関係のない Copepoda，Cladocera のみが発見され，後者にとってはクラゲは単なる庇護物と思われることをのべ，そ の他の幼稚魚の例についても紹介している。また, NICHOLSKY（1963）は, キタュウレ イクラゲ Cyanea cipillaria の笠の下にハドック, タラその他の幼魚が見られ, これら 幼魚とクラゲとの関係はイソギンチヤクとクマノミ属 Amphiprion の関係と同様に見ら れること，ハイチでは 1 個体のクラダの傘下に 300 個体ほどの稚魚がすみついて, クラゲ 
による害を全く受けていない例などを紹介している。

これに対して甲殼類とクラゲとの共生の例についての報告は少なく，わずかに端脚類 Amphipoda のクラゲノミ Hyperia が Pelagia, Aurelia, Cyanea に属するクラゲの 下傘部に見出されること，及び，これと多少事情は異なると思われるが，鉢水母に蔓脚類 Cirripedia のクラゲエボシ Alepas が着生することなどが知られているにすぎない。ク ラゲノミとクラゲとの関係については, 内田（1943，1961）はクラゲ/ミがクラゲの寒天 質や中嘐を食害するとのべ，椎野（1964）は，共生とも考兄られるが多少宿主を食う場合 もあるとしている。

この他には SyoJima (1963) が, Aurelia, Dactylometra に伴うウチワェビ Ibacus ciliatus の Scyllarid phylosoma について報告し, ウチワェビに伴われたクラゲには口 腕部 oral arm を食害されて失っているものがあることを述べている。しかし，この場 合は phyllosoma がクラゲを庇護物として利用していないし，相互の体の大きさなどか ら，これまで述べて来たよらな共生的な相互関係とは違ったものと考兄られる。

さて，ここに報告するシマイシガニ Charybdis cruciata の生活史はまだ知られてい ない。しかし，おそらく近縁のイシガニCharybdis japonicusなどのそれとほぼ似たも のであろらと予想される。また短尾亜目の他のいくつかの種類については, すでにその後 期幼生の生活も明らかであって, 即ち変態の途上 megalopa 後期又は幼蟹初期にそれま での浮游生活から一転して成体と注注同様な生活環境を求め, そこに適応同化して生活す るよらになるものであることも知られている。

この点から見れば，ここに紹介するシマイシガニの生活ぶりは甚だ特異といわなければ ならない。上述のように, 腹肢の発育程度から見て, この個体は初期の幼蟹であると思わ れるが，シマイシガ二の生活史で幼期にこのような生活を造る時期があるのであろうか。 或いは，更に幼ない時期にクラゲの口腕部に迷入したものがそこで成長し，そのまますみ つくようになったものであるとするか，若しくは， ワタリガニ科 Portunidae のカニに は幼蟹期を（ときには成体も）洋上に浮漂する流れ藻に頼って生活するものが少なくない 事実と考え合わせて, 単なる庇護物を求めてクラゲの傘下に偶然すみついていたものと考 觉るのが妥当であるか子知れない。

因みにこのカ二の分布域は広く, SAKAI（1940）によれば, インド洋起源の南方種で, 紶海から東南アジアを経て伊豆半島を北限としているが，相模湾奥部の江＼cjkstart島附近でも成 体はしばしば採集されている。

既述の観察結果から見れば，このカニとクラゲとの関係は友好的な Symbiosis 或いは Synoekosis ではなく, 宮地・森（1953）の Exploitor と Exploited の関係になると思 われる。

\section{謝辞}

この報文をまとめるに当って，東京水産大学妹尾次郎教授には校閲を掞ねがいし，文献 参照に当っても懇篤な御指導をいただいた。また九州大学内田恵太郎名誉教授, 西海区水 
産研究所庄島洋一氏には, 文献の御教示御恵与を招水がいし, 江/島水族館, 金沢水族館 の方々には発表の機会と協力を与只られた。こに併せて厚く叔礼申上げる次第である。

\section{Résumé}

An interesting habit in some of the younger fish belonging to the Suborder Stromateina, that accompanying the jellyfish, is well known as an example of commensalism. In the young crab such habit as mentioned above, has not yet been known.

On October 5, 1962, two individuals of jellyfish, Rhopilema esculenta $\mathrm{K}_{\mathrm{I}}$ SHINOUYE, were obtained off the coast of Enoshima in Sagami Bay and were reared in an inspection tank of the Enoshima Aquarium in Kanagawa Prefecture.

They were consecutively bred till October 22, and the attention of the author was attracted to one of the specimens which was accompanied with two small crabs.

The small crab was identified as a juvenile male of Charybdis cruciata (Herbst), measuring $9.7 \mathrm{~mm}$ in carapace length and $12.9 \mathrm{~mm}$ in carapace width. The life history of Charybdis cruciata, is unknown at present, but it seems to be similar to that of the related species, Charybdis japonica A. M.-EDwards.

In most of the Brachyuran carbs, the habitat and habit of the yonnger stage - Megalopa and early crab-stage - are gradually corresponding to those of the adult in the course ot the development. It is noteworthy that the young of Ch. cruciata has been found living among the oral arms of the jellyfish, however, whether this fact is due to commensalism or to a mere accident is not certain to conclude at present. The author regards, however, the ecological terminology "exploitation" may be properly applied for the present case.

\section{参考文献}

1. AikawA, H. 1937 Further Notes on Brachyuran Larvae. Rec. Oceanog. Works. Jap. 9, pp. 87 162.

2. 蒲 生 重 男 1958 スナガニ科蟹類 2 種の後期幼生。動雑, 67 (3) pp. 68 73

3.—1958 a イワガニ科モクズガニ亜科 2 種の後期幼生。動雑, 67 (12) pp. $373 \sim 379$.

4. Hyman, O. W. 1920 The Development of Gelassimus after Hatching. Jour. Morph. 23, pp. $485 \sim 524$. 
5. KATO, K. 1933 Is Nomeus a Harmless Inquilinus of Pbysalia? Proc. Imp. Acad. (学士院報告) 9 (9) pp. 537 538.

6. 宮地伝三郎・森圭一 1953 動物の生態。岩波全書, 179 , 岩波書店.

7. 村 岡 健 作 1963 ショウジンガニ (Plagnsia deutipes DE HAAN) の後期幼生 の第二次性徴について。甲殼類の研究, 1 pp. $54 \sim 65$.

8. 中 沢 毅 - 1930 甲殼類, 岩波生物学講座。岩波書店.

9. ODUM, H. T. 1953 Fundamental Ecology（生態学の基礎。京大生態研究グルー プ邦訳，朝倉書店）

10. 酒井恒 1936 日本蟹類図説。三省堂.

11. SAKAI, T. 1938 Studies on the Crabs of Japan III Brachygnatha, Brachyrhyncha (key のみ参照).

12. 1940 Biogeographic Review on the Distribution on Crabs in Japanese Waters. Ocean. Wrks. Jap. 2.

13. SANDOZ, M. \& H. Hopkins 1947 Early Life History on the Oyster Crab, Pinnotheres ostreum (SAY). Biol. Bull. 93 (3) pp. 250 258.

14. 椎 野 季 雄 1964 節足動物 (I) 総説甲殼類・動物系総分類学 7 (上) 中山書店

15. 庄 島 洋 一 1961 クラゲに伴らイボダイ Pseunopsis sp. の幼期について。西海 区水研報, 131, p. $67 \sim 74$.

16. 庄 島 洋一 1962 クラゲに伴らアジ科 Crangidae の稚仔魚について。西海区水 研報 27, pp. 49 59

17. 1963 Scyllarid Phyllosomas habit of aecomaanying jellyfish (Preliminary report)。日水会誌, 29 (4) pp.349 353

18. 内田亨

19. 1943 腔腸動物概論・系統動物学。第 1 巻,（直接参照できなかった） 1961 中生・海綿・腔腸・有節動物・動物系統分類学 2 , 中山書店. 